\title{
Factors Influencing the Internationalization of Services Firms: The Case of Design, Engineering and Architecture Consulting Firms
}

\author{
Maria R.A. Moreira ${ }^{1}$, Miguel A.S. Maia ${ }^{1}$, Paulo S.A. Sousa ${ }^{1,2}$, \\ and Raquel F.Ch. Meneses ${ }^{1}$ \\ ${ }^{1}$ Faculty of Economics, Universidade do Porto, \\ R.Dr. Roberto Frias, s/n, 4200-464 Porto, Portugal \\ ${ }^{2}$ LIAAD-INESC Porto LA, Portugal \\ mrosario@fep.up.pt, miguelmaia_esmz@hotmail.com, \\ \{paulus, raquelm\} @fep.up.pt
}

\begin{abstract}
Globalization has created countless opportunities for the internationalization of a wide range of services. Recent technological innovations associated with the reduction or elimination of trade barriers, resulted in an exponential expansion of service firms. This paper analyzes the internal and external factors that influence the decision to operate internationally. The hypotheses are empirically examined through a survey sent to 322 firms from the design, architecture and engineering sector. Multivariate analysis is used to ascertain the main determinants of internationalization in these firms.

The findings indicate that the main reasons underlying the internationalization of these service firms are the size of the firm, the competitive environment and the staff's degree of international experience. These factors, which influence the management's attitudes toward operating internationally, determine the firm's degree of internationalization. Moreover, firms that have a high number of senior managers with a graduate course and higher skills in foreign languages are more prone to internationalize. Some practical implications are presented for service firms that are in the process of internationalizing.
\end{abstract}

Keywords: Internationalization, service firms, exportation, influencing factors.

\section{Introduction}

The globalization of businesses and recent technological innovations as well as the reduction or even elimination of trade barriers and the celebration of international service trade agreements (General Agreement on Trade in Services and the European Union Service Directive), have created numerous opportunities for the service industry in the world economy.

The service sector represents about $67 \%$ of the GDP worldwide and about $55 \%$ of the GDP of developed countries [1]. In the OECD countries, the service sector has been strongly converted to generate employment, being responsible for more than 
$70 \%$ of total employment. However, in the majority of these countries, the increase in productivity is much slower, a fact that led the OECD to stress the need for further research in order to detect how services can be more competitive and go international. This is also the reason why we decided to study the factors that influence the internationalization of services. The literature has generally only provided models and theories focusing specifically on the internationalization process of industrial organizations, and some of the models and approaches to services still lack empirical validation [2-3]. In addition there are conflicting views in the literature on the applicability of the existing theories to services [4-5]. Indeed, several studies (e.g. [6]) highlight that future research on the internationalization of management consultancy should aim to build on the existing exploratory effort, using a quantitative research design approach.

The main aim of this study was to analyze the factors that influence design, architecture and engineering consulting firms to operate internationally, and to quantify the impact of these factors. Although a number of studies have explored this matter, they are mostly based on a single case study approach (e.g. [7]), and not a quantitative one. To accomplish this objective, we analyzed the companies' internal and external features, their structure, perceived barriers to internationalization and the determinants behind the choice of a certain country. The research methodology used, in line with studies in the area, was the quantitative analysis of surveys sent to 322 firms from the design, architecture and engineering consulting sector. An exploratory analysis of different hypotheses was also conducted based on the literature review.

Moreover, multivariate analysis was employed to ascertain the main determinants of internationalization and the results were compared with those from studies on other countries in order to determine similarities and differences among distinct economic, geographic and social realities.

This paper begins with a brief review of the relevant literature on the aspects involved in the research (services' features, internationalization strategies and theories). Subsequently, the methodology used is described, the results of statistical analysis are presented and the analysis and quantification of the impact of the factors that influence design, architecture and engineering consulting firms to operate internationally is made (aim 2). The paper ends with the conclusion, describing the study's limitations and paths for future research.

\section{Theoretical Background}

Several studies (e.g. [5], [8]) identify the features that distinguish services from manufactured goods: (1) intangibility (services are not transportable or storable), (2) inseparability (production and consumption occur simultaneously), (3) perishability (services cannot be saved and must be consumed as they are produced), and (4) heterogeneity (services are unique and difficult to standardize). Intangibility is, according to Bateson and Hoffman [9], the mother of all the differences between services and goods. This feature constitutes a challenge to all firms that want to enter new markets, especially international ones, due to linguistic and cultural barriers. Moreover, services have different degrees of these characteristics: there is a continuum between pure goods and pure services. 


\subsection{Internationalization Strategies in Services}

When studying the different forms of internationalization, it appears that export activities tend to be more risky when made by service organizations than those conducted in industrial organizations [10]. This occurs due to the fact that the products / goods of services have, as we have seen, distinct features [8]. Most of the literature on internationalization and its strategies are guided by the needs of the industrial sector [10]. There is therefore a lack of literature on the strategies used by service providers.

According to Grönroos [10] and [11], the literature is divided into three streams. In the first stream, some authors (e.g., [12-13]) argue that the internationalization of service companies and manufacturing industries go through a similar process and that there is no need to adapt existing models of internationalization. A second group of authors (e.g., [14-15]) argues that there are significant differences between the internationalization of a product (material) and a service (immaterial/intangible). A third group of authors (e.g., [16-17]) is of the opinion that the internationalization of service firms cannot be considered in general, since there should be a distinction between different types of services. Erramilli [16] divides the services into hard services (e.g., architectural design, insurance) and soft services (e.g., catering, healthcare).

Five key strategies for the internationalization of services can be identified regardless of the characteristics and type of service: 1) Direct export, 2) Export in partnership; 3) Direct entry, 4) Indirect entry (joint venture with local company); 5) Electronic commerce [10]. The strategies are not mutually exclusive and, in some cases, are similar to the strategies of the companies that produce goods [10].

The literature shows ambiguities ([2], [10]) and different perspectives regarding the internationalization strategies of service firms ([12], [15], [18-19]), mostly as a consequence of the features of services. Concerning the entry modes, it is unanimous that, in service companies, they are similar to those used by manufacturing companies [10]. The literature also stresses the use of new technologies, such as the internet, as a strategy and entry mode for service firms [10], [20].

\subsection{The Applicability of Internationalization Theories to Service Providers}

Several theories have been presented as approaches that explain the internationalization of firms which may be applied to the service sector. These can be divided into two major groups [3]: economic approaches (Internalization, Eclectic Paradigm) and behavioral approaches (Uppsala School, Networks, Business Strategy and Resource-Based View). The description of each theory is summarized in Table 1.

\subsection{Theories of Internationalization and Service Providers}

The theories listed above describe the different aspects of the complex phenomenon of the internationalization of firms. However, according to Coviello and McAuley [41], those theories do not compete nor are they mutually exclusive, but rather, they complement each other. Each theory has its own specific advantages and disadvantages [14]. 
Table 1. Summary of the theories of internationalization

\begin{tabular}{|c|c|c|}
\hline $\begin{array}{c}\text { Internatio- } \\
\text { nalization } \\
\text { theories }\end{array}$ & Definition/description & Authors \\
\hline $\begin{array}{l}\text { Internaliza- } \\
\text { tion Theory }\end{array}$ & $\begin{array}{l}\text { The theory is based on the analysis of transaction costs. The axiom of the } \\
\text { general internalization theory is that firms choose the location of } \\
\text { internationalization, as well as the maintenance mode in the market, whereby } \\
\text { the overall transaction costs are minimized. }\end{array}$ & [3], [21] \\
\hline $\begin{array}{l}\text { Eclectic } \\
\text { Paradigm }\end{array}$ & $\begin{array}{l}\text { The theory is based on transaction costs and analyzes the transfers and rewards of } \\
\text { the firms' ownership. It points to several reasons for companies to start operations } \\
\text { abroad: market demand, increasing efficiency, seeking strategic assets and } \\
\text { capabilities outside their country. According to Andersen (27), the eclectic } \\
\text { paradigm is a synthesis of the internalization theory and the transaction costs. }\end{array}$ & $\begin{array}{c}{[15],} \\
{[21-24]}\end{array}$ \\
\hline $\begin{array}{c}\text { Uppsala } \\
\text { School }\end{array}$ & $\begin{array}{l}\text { The Uppsala model examines the expansion to foreign markets, trying to identify } \\
\text { the various stages at which such expansion occurs. It describes the } \\
\text { internationalization as a behavioural process through which a company moulds } \\
\text { itself to the internationalization process in incremental and sequential stages, as a } \\
\text { result of the development of knowledge and learning. The model advocates } \\
\text { internationalization in stages due to the lack of knowledge and due to uncertainty. }\end{array}$ & $\begin{array}{c}{[21],} \\
{[25-27]}\end{array}$ \\
\hline $\begin{array}{l}\text { Theory of } \\
\text { Networks }\end{array}$ & $\begin{array}{l}\text { The theory argues that the development in the international market does not only } \\
\text { depend on the combination of the company's competitive advantages. The } \\
\text { success of internationalization depends on the networks and on the strategic } \\
\text { alliances developed. These networks involve both external and internal networks. }\end{array}$ & [28-34] \\
\hline $\begin{array}{l}\text { Business } \\
\text { Strategy }\end{array}$ & $\begin{array}{l}\text { According to this, companies take into account a wide range of variables when } \\
\text { looking at the benefits and costs of internationalization. Two groups of variables } \\
\text { are identified as relevant: external factors (e.g., workforce, market's accessibility } \\
\text { and attractiveness, cultural distance, ease of transportation) and internal factors } \\
\text { (e.g., size, industry, capital resources, and experience in international trade). }\end{array}$ & {$[3],[35]$} \\
\hline $\begin{array}{c}\text { Resource- } \\
\text { Based View }\end{array}$ & $\begin{array}{l}\text { This view argues that firms with scarce, valuable and inimitable resources } \\
\text { generate competitive advantages, and thus enable higher than normal rates of } \\
\text { return. The attributes of the companies are the fundamental drivers of } \\
\text { performance and the sustainable advantage necessary for internationalization. }\end{array}$ & [36-40] \\
\hline
\end{tabular}

Over the last decade, there has been a lively debate on the applicability of stage models of internationalization to service firms [42]. The criticism is centred on a series of studies that found that the conventional theory of stages of internationalization (Uppsala Model) does not adequately explain the process of internationalization of certain businesses, especially small [30].

Regarding the theory of networks, the literature emphasizes the collaborative nature of the internationalization of services based on knowledge and contact networks ([14], [30]). However, due to the nature of the services, they require greater customer-producer interaction than goods, which hinders the standardization of the product, since each customer wants a custom service. Moreover, this theory focuses only on the interdependencies between the actors [3]. Thus, the theory of networks provides only a partial explanation for the internationalization of services and needs to be complemented with broader aspects of company strategy [3].

The approach to business strategy, compared with the approaches mentioned above, is more comprehensive and seems to be flexible enough to deal with the development, characteristics and objectives of service companies [3]. Additionally, it is able to capture the influence of the environment [14]. One criticism, though, notes that this approach places excessive focus on the value of business characteristics, rather than on value creation. 


\section{Methodology}

Based on the conceptual model presented by Patterson [4], we studied the relationships between the different determinants and the tendency of service firms to globalize.

\subsection{Key Elements in the Decision to Internationalize and Hypotheses}

To identify the key elements, it is necessary to determine, in accordance with the theories of internationalization, which features to include in the study and which theories best explain the internationalization of services.

The model proposed by Patterson [4] uses more than one underlying theory for the construction of its analysis scheme. The conceptual model adopted is based on the following theoretical views: the Resource-Based View, the Business Strategy and the Uppsala Model. The theories suggest several categories of factors that need to be incorporated in the model. In this context and in line with Patterson [4], the following five factors should be used as key elements: 1) Capacities and characteristics of firms, 2) Barriers to internationalization, 3) Perceptions of the risks and benefits of internationalization; 4) Competitiveness; and 5) Management features. (Figure 1).

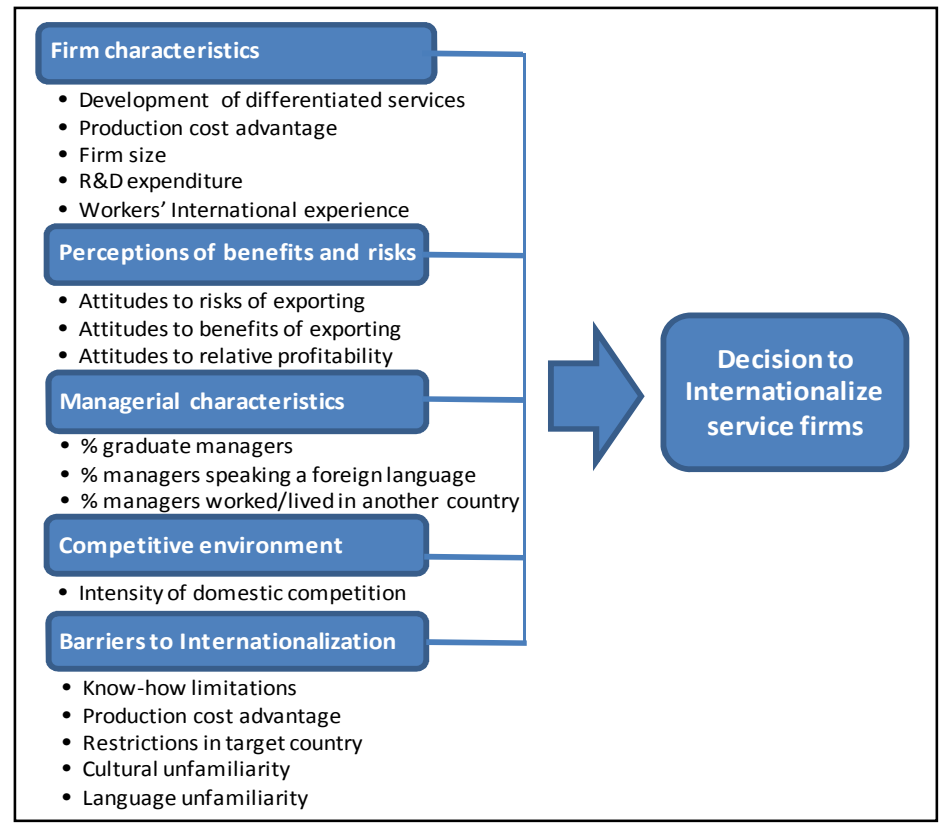

Fig. 1. Determinants of the service companies' decision to internationalize (Adapted from Patterson [4])

Based on each key element, a set of hypotheses were formulated, as discussed by several authors, which are summarized in the Table 2. 
Table 2. Research hypotheses

\begin{tabular}{|c|c|c|}
\hline $\begin{array}{c}\text { Key } \\
\text { elements }\end{array}$ & Research hypothesis & Authors \\
\hline \multirow{4}{*}{ 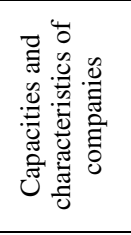 } & H1- Firm size is positively related with the decision to operate internationally. & [4], [44] \\
\hline & $\begin{array}{l}\text { H1a: Companies that have a higher number of employees with international } \\
\text { experience are the most active internationally. }\end{array}$ & {$[45-46]$} \\
\hline & $\begin{array}{l}\text { H1b: Companies that have advantages in production costs or differentiated } \\
\text { products are the most active internationally. }\end{array}$ & $\begin{array}{c}{[4],} \\
{[47-48]}\end{array}$ \\
\hline & $\begin{array}{l}\text { H1c: Firms that have higher investments in } \mathrm{R} \& \mathrm{D} \text { maintain more regular } \\
\text { contacts with international markets. }\end{array}$ & {$[4]$} \\
\hline \multirow{4}{*}{ 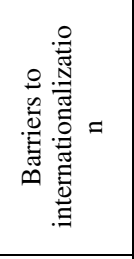 } & $\begin{array}{l}\mathrm{H} 2 \text { - Existing restrictions in the destination country (customs costs and initial } \\
\text { investment costs) are perceived as the main obstacle to internationalization. }\end{array}$ & [4], [49] \\
\hline & $\begin{array}{l}\text { H2a: Unawareness of linguistic and cultural differences of the foreign markets } \\
\text { are perceived as a major barrier to internationalization. }\end{array}$ & [49-51] \\
\hline & $\begin{array}{l}\text { H2b: Limitations in know-how are perceived as the most significant obstacle to } \\
\text { internationalization }\end{array}$ & [4] \\
\hline & $\begin{array}{l}\text { H2c: Protectionism of local technicians and companies is a barrier to the } \\
\text { internationalization of service firms. }\end{array}$ & $\begin{array}{l}\text { Explora } \\
\text {-tory }\end{array}$ \\
\hline \multirow{2}{*}{ 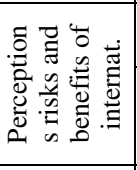 } & $\begin{array}{l}\text { H3 - The attitudes and perceptions regarding the risk of internationalization } \\
\text { differ between companies operating and not operating internationally. }\end{array}$ & $\begin{array}{c}{[4],} \\
{[52-54]}\end{array}$ \\
\hline & $\begin{array}{l}\text { H3a: Companies that do not operate internationally regard internationalization } \\
\text { as being more expensive, with higher risks and less profitable than firms that } \\
\text { already have contacts with the international market. }\end{array}$ & $\begin{array}{c}{[52]} \\
{[54-55]}\end{array}$ \\
\hline $\begin{array}{l}\text { Competi } \\
\text {-tiveness }\end{array}$ & $\begin{array}{l}\text { H4 - Companies that experience (and understand) the high competitive } \\
\text { intensity of domestic markets, have greater contact with international markets } \\
\text { than those who do not face such domestic pressures. }\end{array}$ & [4], [53] \\
\hline \multirow{3}{*}{ 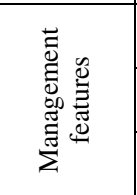 } & $\begin{array}{l}\text { H5 - Companies with a higher number of graduate managers maintain more } \\
\text { regular contacts with international markets. }\end{array}$ & [4-5] \\
\hline & $\begin{array}{l}\text { H5a: Companies with a higher number of employees with skills in foreign } \\
\text { languages maintain more regular contacts with international markets. }\end{array}$ & {$[4-5]$} \\
\hline & $\begin{array}{l}\text { H5b: Companies that have a large number of workers who have worked abroad } \\
\text { are the most active internationally. }\end{array}$ & $\begin{array}{c}{[4-5]} \\
{[56]}\end{array}$ \\
\hline
\end{tabular}

\section{2 'Theoretical' Model Specification}

According to the theoretical approaches examined in the previous sections and from the key elements and hypotheses described above, we present the determinants that may explain the decision to internationalize in the service sector. They are grouped according to their characteristics and following the Patterson (2004) model:

1) Capacities and characteristics of companies, including firm size (Size), the number of services provided by the company (Num_Serv), and the level of investment in R\&D (Inv_RD);

2) Barriers to internationalization, which includes the number of perceived barriers (Num_Barr), the importance attributed to the initial investment costs (Imp_InvCosts), the importance given to cultural differences (Imp_DifCult) and language (Imp_DifLang), the importance attributed to know-how limitations (Imp_LimKH), perceptions of protectionism for local technicians (Imp_ProtTecn), and the degree of unfamiliarity with the foreign market (Unfam_Mkt);

3) Perceptions of the risk and benefits of internationalization, which encompasses the perceived risk of operating internationally (Perc_Risk), the perception of the cost (Perc_Cost), and the perception of its profitability (Perc_Profit); 
4) Competitiveness, which includes the intensity of national competitiveness (Int_Competitive);

5) Management features, which covers the number of graduate managers (Num_GManager), the foreign language skills of managers (Num_Lang), and the employees' international work experience (Int_Exp).

In this study, we used multivariable estimation techniques to assess the extent to which variables such as firm size, degree of skilled personnel or the importance of market diversification affects the decision to internationalize. The following equation represents the 'theoretical' model adopted:

Dec_Internat $=\left(\begin{array}{c}\text { Size; Num_Serv; Inv_RD } \\ \text { Num_Barr; Imp_InvCosts; Imp_DifCult; Imp_DifLang; Imp_LimKH; Imp_ProtTecn; Unfam_Mkt } \\ \text { Perc_Risk; Perc_Cost; Perc_Profit } \\ \text { Int_Competitive } \\ \text { Num_GManager; Num_Lang; Int_Exp }\end{array}\right)$

The following table (Table 3) summarizes the determinants considered in the 'theoretical' model as well as information on the sources and the expected effect on the decision to internationalize.

Table 3. Determinants of the 'theoretical' model

\begin{tabular}{|c|c|c|c|c|}
\hline Group & Determinant & $\begin{array}{c}\text { Variable } \\
\text { measurement }\end{array}$ & Source & $\begin{array}{c}\text { Expe } \\
\text { cted } \\
\text { signal }\end{array}$ \\
\hline \multicolumn{2}{|c|}{ Decision to Internationalize } & \begin{tabular}{|lr} 
Yes/No question \\
regarding operate/have \\
contact internationally
\end{tabular} & $\begin{array}{l}\text { Question- } \\
\text { naire }\end{array}$ & \\
\hline \multirow{5}{*}{ 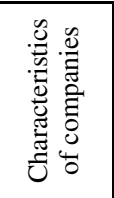 } & \multirow{3}{*}{ Firm Size } & Turnover (2009) & SABI & + \\
\hline & & Employees (2009) & SABI & + \\
\hline & & Turnover/employees & Calculus & + \\
\hline & Number of services provided by the company & Number of services & \multirow{16}{*}{$\begin{array}{l}\text { Question- } \\
\text { naire }\end{array}$} & + \\
\hline & Level of investment in R\&D & Amount (in Euros) & & + \\
\hline \multirow{7}{*}{ 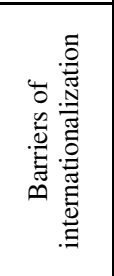 } & Number of perceived barriers & Number of obstacles & & - \\
\hline & Importance attributed to initial invest costs & \multirow{10}{*}{$\begin{array}{l}\text { Likert scale } \\
\text { (5 points) }\end{array}$} & & - \\
\hline & Importance given to cultural differences & & & - \\
\hline & Importance given to language difference & & & - \\
\hline & Importance attributed to know-how limitations & & & - \\
\hline & Perceptions of protectionism for local & & & - \\
\hline & Degree of unfamiliarity with the foreign & & & - \\
\hline \multirow{3}{*}{ 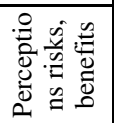 } & Perceived risk of operating internationally & & & - \\
\hline & Perception of the cost & & & - \\
\hline & Perception of its profitability & & & + \\
\hline \multicolumn{2}{|c|}{ Intensity of national competitiveness } & & & + \\
\hline \multirow{3}{*}{ 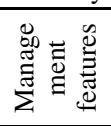 } & Number of graduate managers & \multirow{3}{*}{ Value provided } & & + \\
\hline & Foreign language skills of managers & & & + \\
\hline & $\begin{array}{llll}\mathrm{N}^{\circ} & \text { employees } & \text { with } & \text { international } \\
\end{array}$ & & & + \\
\hline
\end{tabular}




\subsection{Description of the Population and Sampling Criteria}

Based on the literature review, the questionnaire focused on the five key elements just described. The questionnaire in its final form consisted of nineteen questions and was sent electronically (e-mail) directly to the head of the selected companies.

According to Yin [57], the sample should consist of a group of companies that belong to the population and there should be a correspondence between the structure of the samples and the structure of the population. Thus, the survey was administered to the 375 biggest firms (turnover volume) from the design, architecture and engineering consulting sector (in the SABI - System Analysis of Iberian Balance database). Further information was requested from the sector's association - the APPC (Portuguese Association of Engineering and Management Consultants) having also sent questionnaires to 183 members of the APPC. 74 members of the APPC were already among the 375 largest companies in the sector (obtained via SABI). During the contact process, it was found that some companies were insolvent or had been dissolved, were unreachable or not eligible for the questionnaire. Therefore, the final number of companies that received the questionnaire was 322 . From these 322 companies, only 54 companies responded. All the questionnaires were valid for statistical analysis, representing a response rate of $16.8 \%$, which puts this study in parity with other studies.

\section{$4 \quad$ Empirical Results}

First, a descriptive analysis of the questionnaire answers is conducted, followed by the empirical validation of the research hypotheses, and finally, the key findings are presented and discussed in light of the existing literature.

\subsection{Descriptive Analysis and Validation of Research Hypotheses}

The companies that responded to the questionnaire had a turnover (for 2009) of 261.055 thousand euros and employed 2584 workers. On average, each company had an annual turnover of about 4.834 thousand euros and 48 employees. Moreover, $70 \%$ of them are involved in engineering projects and 66\% are dedicated to project management.

The respondent companies regard international markets as riskier and more expensive to operate, but more profitable than domestic markets. These results are fully in line with those reported by Winsted and Patterson [53]. With regard to competitiveness, we found that the firms surveyed assume that the domestic market is saturated or exhausted.

The barriers/obstacles to internationalization can create structural and operational constraints that often result in failures in the internationalization process. According to Patterson [4], the obstacles are one of the most important key elements in the decision to globalize.

Most companies consider that protectionism of local technicians and companies (in the country where the company can internationalize) is the main obstacle to their internationalization, followed by the costs associated with the initial investment. We can also add the obstacle associated to unfamiliarity with the foreign market. 
In order to test the research hypotheses, the IBM SPSS Statistics software (version 19.0) package was used. Table 4 shows the tests employed to validate each hypothesis as well as the p-value obtained and the decision concerning the hypothesis.

Table 4. Statistical test results

\begin{tabular}{|c|c|c|c|c|}
\hline Key elements & $\begin{array}{l}\text { Research } \\
\text { hypothesis }\end{array}$ & Statistical Test & $\begin{array}{c}\text { p- } \\
\text { value }\end{array}$ & Decision \\
\hline \multirow{4}{*}{$\begin{array}{l}\text { Capacities and characteristics of } \\
\text { companies }\end{array}$. } & H1 & \multirow{4}{*}{ Mann-Whitney } & 0.004 & Reject H0 \\
\hline & $\mathrm{H} 1 \mathrm{a}$ & & 0.000 & Reject $\mathrm{H} 0$ \\
\hline & $\mathrm{H} 1 \mathrm{~b}$ & & 0.335 & Retain $\mathrm{H} 0$ \\
\hline & $\mathrm{H} 1 \mathrm{c}$ & & 0.051 & Retain $\mathrm{HO}$ \\
\hline \multirow{4}{*}{ Barriers to internationalization } & $\mathrm{H} 2$ & \multirow{3}{*}{ McNemar } & 0.556 & Retain $\mathrm{H} 0$ \\
\hline & $\mathrm{H} 2 \mathrm{a}$ & & 0.000 & Reject H0 \\
\hline & $\mathrm{H} 2 \mathrm{~b}$ & & 0.000 & Reject H0 \\
\hline & $\mathrm{H} 2 \mathrm{c}$ & Friedman & 0.042 & Reject H0 \\
\hline \multirow{2}{*}{$\begin{array}{l}\text { Perceptions of the risk and benefits of } \\
\text { internationalization }\end{array}$} & $\mathrm{H} 3$ & \multirow{2}{*}{ Mann-Whitney } & 0.764 & Retain $\mathrm{HO}$ \\
\hline & $\mathrm{H} 3 \mathrm{a}$ & & 1.00 & Retain $\mathrm{H} 0$ \\
\hline Competitiveness & $\mathrm{H} 4$ & Mann-Whitney & 0.261 & Retain $\mathrm{H} 0$ \\
\hline \multirow{3}{*}{ Management features } & $\mathrm{H} 5$ & \multirow{3}{*}{ Mann-Whitney } & 0.039 & Reject H0 \\
\hline & $\mathrm{H} 5 \mathrm{a}$ & & 0.023 & Reject H0 \\
\hline & $\mathrm{H} 5 \mathrm{~b}$ & & 0.54 & Retain $\mathrm{HO}$ \\
\hline
\end{tabular}

According to the results of the hypothesis tests performed concerning H1, firms that have a higher turnover are more prone to internationalization. This finding is in line with Patterson [4] and Castellacci [44]'s results. Moreover, in the case of Portuguese firms, and in line with the findings presented by Hassel et al. [45] for Germany, the number of employees with international experience is higher in firms that operate internationally (H1a).

The hypothesis that firms that have a broader variety of services (differentiated "products") (H1b) are the most active internationally stems from the conclusions drawn by Coviello and Martin [47], Zou et al. [48] and Patterson [4]. However, no conclusions can be drawn about the impact of this variable on the decision to internationalize or not. For companies in the service sector in analysis, the diversity of services does not seem to influence their level of internationalization. The same can be concluded for H1c.

With respect to the barriers to the internationalization, Samiee [49] and Patterson [4] suggest that costs are the major obstacle, whereas Guenzi and Pelloni [50] and Sichtmann [51] indicate unawareness of linguistic and cultural differences as the main barrier. Patterson [4] also considers that a major barrier to internationalization is limitations in know-how. In our study, the three obstacles to which companies attributed the most importance as barriers to internationalization are protectionism to local technicians and businesses, unfamiliarity with the foreign market and the costs of initial investment.

Regarding the other factors, it should be noted that Portuguese companies whose management structures include graduate managers with foreign language skills are more prone to internationalize (H5 and $\mathrm{H} 5 \mathrm{a})$. 
As for the companies' perception of the risk of operating internationally, of profitability and costs, it seems that these do not influence the company's level of internationalization, in contrast with the findings of Aaby and Slater [52], Leonidou et al. [54] and Patterson [4]. The diversity of services offered, more competitive factor prices, the level of investment in R\&D and the pressure of the internal market show no statistically significant influence on the company's level of internationalization.

\subsection{Differences on Averages, Correlations between Variables and Implications for the Model}

In this section, an exploratory analysis of data is conducted and the relationships between the 'theoretical' model's variables are explored, so as to complement the validation of the research hypotheses. To accomplish this analysis, the Mann-Whitney test was employed, to assess whether there is evidence of significant statistically differences between the averages of each group (firms that operate internationally and firms that do not act in the international market), in the various dimensions of the variables not included in the previous section. Table 5 summarizes the information on the average differences of all variables.

Table 5. Differences in averages - Mann-Whitney test

\begin{tabular}{|c|c|c|c|c|c|c|}
\hline Group & Determinant & $\begin{array}{c}\text { Variable } \\
\text { measurement }\end{array}$ & $\begin{array}{c}\text { All } \\
\text { companies }\end{array}$ & \begin{tabular}{|} 
Firms not in \\
the \\
international \\
market
\end{tabular} & \begin{tabular}{|l|} 
Firms that \\
operate \\
intern.
\end{tabular} & $\begin{array}{c}p \text {-value } \\
(\mathrm{M}-\mathrm{W})\end{array}$ \\
\hline \multirow{5}{*}{ 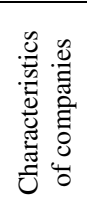 } & \multirow{3}{*}{ Firm Size } & Turnover (2009) & $4.834,35$ & $1.749,23$ & $5.812,56$ & $0.004^{\mathrm{a}}$ \\
\hline & & Employees (2009) & 48 & 16 & 58 & $0.002^{\mathrm{a}}$ \\
\hline & & Turnover/employees & 114.6 & 117.61 & 113.64 & 0.326 \\
\hline & $\mathrm{N}^{\mathrm{o}}$ services provided by company & $\mathrm{N}^{\mathrm{o}}$ services selected & 3.85 & 4.46 & 3.66 & 0.335 \\
\hline & Level of investment in R\&D & Amount (in Euros) & 72.05 & 12.86 & 92.85 & $0.051^{\mathrm{b}}$ \\
\hline \multirow{7}{*}{ 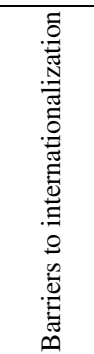 } & Number of perceived barriers & $\mathrm{N}^{\mathrm{o}}$ obstacles selected & 2.15 & 2.0 & 2.2 & 0.657 \\
\hline & Imp. attributed to init. invest costs & \multirow{10}{*}{$\begin{array}{l}\text { Likert scale } \\
(5 \text { points })\end{array}$} & 3.36 & 3.85 & 3.19 & 0.133 \\
\hline & Imp. given to cultural differences & & 2.45 & 2.33 & 2.49 & 0.78 \\
\hline & Imp. given to language differences & & 2.67 & 2.58 & 2.69 & 0.819 \\
\hline & Imp. attributed to know-how lim. & & 2.62 & 3.0 & 2.5 & 0.193 \\
\hline & $\begin{array}{l}\text { Perceptions of protectionism for } \\
\text { local technicians }\end{array}$ & & 3.14 & 3.36 & 3.08 & 0.558 \\
\hline & $\begin{array}{l}\begin{array}{l}\text { Degree of unfamiliarity of the } \\
\text { foreign market }\end{array} \\
\end{array}$ & & 3.10 & 3.83 & 2.88 & $0.009^{\mathrm{a}}$ \\
\hline \multirow{3}{*}{ 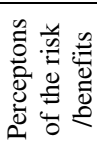 } & \begin{tabular}{|l} 
Perceived risk of operating \\
internationally
\end{tabular} & & 3.5 & 3.62 & 3.46 & 0.764 \\
\hline & Perception of the cost & & 4 & 4 & 4 & 1.00 \\
\hline & Perception of its profitability & & 3.43 & 3.23 & 3.49 & 0.155 \\
\hline \multicolumn{2}{|c|}{ Intensity of national competitiveness } & & 4.22 & 4.0 & 4.29 & 0.261 \\
\hline \multirow{3}{*}{ 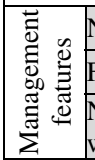 } & Jumber of graduate managers & \multirow{3}{*}{ Value provided } & 6.38 & 4.23 & 7.07 & $0.039^{\mathrm{a}}$ \\
\hline & oreign language skills of managers & & 6.3 & 4 & 7.02 & $0.023^{\mathrm{a}}$ \\
\hline & $\begin{array}{l}{ }^{\circ} \text { employees with international } \\
\text { vork experience }\end{array}$ & & 12.7 & 1.23 & 16.34 & $0.000^{\mathrm{a}}$ \\
\hline
\end{tabular}


Based on the Mann-Whitney test for differences in means between firms operating abroad and firms that operate only in the domestic market, significant differences were found in only three of the five groups of determinants into which the variables were classified. In the group concerning Characteristics of Firms, we found significant differences in the determinants 'Company size' and 'Level of Investment in R\&D'; in the group Barriers to internationalization, only in the determinant 'Importance attributed to unfamiliarity with the external market' presented significant differences. In the last group, Management features, the determinants 'Number of graduate managers', 'Number of managers with foreign language skills' and 'Number of employees with international experience' revealed significant differences between the two groups, with a significance level of 5\%. The analysis suggests the potentially relevant role of firm size, the amount invested in $R \& D$, the importance attributed to unfamiliarity with the external market, the managers' educational level, and the international experience of the workers, with quite different averages between the two groups of companies.

After testing the differences between the two groups of firms for all variables, the multivariate analysis should be preceded by an analysis of the correlation matrix among the relevant variables in order to assess the degree of explanation of the variables and avoid including (explanatory) variables which could be highly correlated.

Based on the analysis of the Pearson coefficients, we can conclude that there is a significant correlation of the dependent variable (internationalization decision) with six variables: firm size (with a Pearson correlation value of 0.412 ), the number of employees (Pearson correlation 0.487), unfamiliarity with the external market ($0.429)$, the number of employees with international experience (0.526), the level of investment in $\mathrm{R} \& \mathrm{D}(0.324)$, the perception of the initial investment costs (Pearson coefficient -0.35$)$, and the number of managers with international experience (0.5). This analysis suggests that, on average, larger companies, companies that invest more in $\mathrm{R} \& \mathrm{D}$, have more employees with international experience, and more graduate managers, tend to internationalize, which confirms the results obtained with the Mann-Whitney test. Moreover, we found that the greater the perception of the initial investment costs and the importance attributed to unfamiliarity with the market, the lower the propensity to internationalize. This finding is also in line with the results obtained using the Mann-Whitney test, with only a slight difference in relation to the initial investment cost.

Analyzing the independent variables, we found that several items are strongly correlated, which could lead to problems of multicollinearity in the estimation. This question can have two meanings: that the variables are measuring the same factor, or that they have a common dependency on another unmeasured variable in the model Maroco, [58]. The variable 'turnover' is strongly related to the number of workers (Pearson correlation coefficient of 0.818 ). We decided to keep only one of them (turnover), because we believe it is more representative of firm size than the number of workers. The variable 'number of graduate managers' reveals a strong correlation with the variable 'number of managers who speak one or more foreign languages' (Pearson correlation coefficient of 0.976 ). Therefore, we opted to keep only one 
variable, the level of graduate managers. A similar situation occurs between the variables 'importance of cultural differences' and 'importance of language differences' (0.694). We decided to eliminate the variable 'importance of language differences' because it has the greatest number of correlations with other variables with a significance level of $5 \%$.

\subsection{Results from the Multivariate Analysis and Discussion of the Results}

In this section, an analysis of causality is performed using multivariate techniques, to analyze the degree of explanation of each variable.

When the dependent variable type is nominal (assuming the value 0 for firms that operate only in the domestic market and 1 for those operating internationally), the appropriate method to estimate the theoretical model is the binary logistic regression. This is the procedure described to model, in probabilistic terms, the occurrence of one of the two achievements of the classes of the variable. The independent variables may be qualitative and/or quantitative. The logistic model can thus assess the significance of each of the model's independent variables.

The following table (Table 6) shows the results of the logistic estimation, using various methods to select the independent variables. The empirical results of the decision to internationalize, based on the logistic regression, has the dummy variable Int_Dec as the dependent variable, which assumes the value 1 if the company operates abroad and 0 otherwise.

Table 6. Empirical results based on logistic regression

\begin{tabular}{|c|c|c|c|}
\hline Group & Determinant & $\begin{array}{l}\text { Method } \\
\text { A }\end{array}$ & $\begin{array}{c}\text { Method } \\
\text { B }\end{array}$ \\
\hline \multirow{4}{*}{$\begin{array}{l}\text { Characteristics } \\
\text { of companies }\end{array}$} & Constant & -7.511 & 6.481 \\
\hline & Firm Size & $2.194^{\mathrm{a}}$ & --- \\
\hline & Number of services provided by the company & --- & --- \\
\hline & Level of investment in R\&D & --- & $5.66^{\mathrm{b}}$ \\
\hline \multirow{6}{*}{$\begin{array}{l}\text { Barriers to } \\
\text { international- } \\
\text { lization }\end{array}$} & Number of perceived barriers & --- & --- \\
\hline & Importance attributed to the initial investment costs & --- & --- \\
\hline & Importance given to cultural differences & --- & --- \\
\hline & Importance attributed to know-how limitations & --- & --- \\
\hline & Perceptions of protectionism for local technicians & --- & --- \\
\hline & Degree of unfamiliarity with the foreign market & $-1.374^{\mathrm{a}}$ & $-2.470^{b}$ \\
\hline \multirow{3}{*}{$\begin{array}{l}\text { Perceptions of } \\
\text { the risk and } \\
\text { benefits }\end{array}$} & Perceived risk of operating internationally & $\overline{---}$ & --- \\
\hline & Perception of the cost & --- & --- \\
\hline & Perception of its profitability & -- & --- \\
\hline \multicolumn{2}{|c|}{ Intensity of national competitiveness } & $1.552^{\mathrm{a}}$ & --- \\
\hline \multirow{2}{*}{$\begin{array}{l}\text { Management } \\
\text { features }\end{array}$} & Number of graduate managers & --- & --- \\
\hline & Number of employees with international work experience & --- & $7.964^{\mathrm{b}}$ \\
\hline & $\mathrm{N}$ & 54 & 54 \\
\hline \multirow{3}{*}{ Goodness of fit } & Hosmer and Lemeshow & 4.059 & 3.489 \\
\hline & (p-value) & 0.852 & 0.9 \\
\hline & $\%$ correct & $81.8 \%$ & $93.1 \%$ \\
\hline
\end{tabular}

${ }^{a}$ significance level of $5 \% \quad{ }^{b}$ significance level of $10 \%$ 
The tests of goodness of fit (Hosmer-Lemeshow test and estimated percentage of correct observations) allow us to conclude that the model using the Forward Stepwise LR method has a good quality adjustment. In fact, concerning the Hosmer-Lemeshow test, a p-value above 0.10 means that it does not reject the null hypothesis, namely that the models represent reality well (and the 2 models have p-values of 0.852 and 0.9 ). Furthermore, over $80 \%$ of the estimated values of the dependent variable are correctly predicted by the models.

The results indicate that, on average, firm size is the key determinant in the choice to internationalize (corresponding to a p-value of $0.045<5 \%$ ). The positive sign and statistically significant estimated coefficient for the firm size, indicates that firms with higher sales volumes tend, on average, to operate more abroad. This relationship confirms the study of Winsted and Patterson (1998). In addition, there are four factors that strongly explain the decision to internationalize. They are the number of workers with international experience ( $\mathrm{p}$-value of 0.058), the domestic competitive pressure (p-value of 0.039), the level of investment in research and development ( $p$-value of 0.041 ), and the importance attributed to unfamiliarity with the market (p-value of $0.049)$.

The positive sign on the number of employees with international experience shows that the more open the company to employees with international experience, the greater the propensity to internationalize. In fact, a company that employs workers with international experience has added impetus to internationalize, not only because of the experience factor (lower risk associated with the uncertainty of the market) but also because the employees can be drivers of change within the company, encouraging the desire to grow across the organization to other more distant markets.

The variable 'domestic competitive pressure' reveals a similar pattern: the positive and statistically significant sign associated with this variable (1.552) means that the more saturated the market, the greater the propensity to internationalize. This result corroborates the study of Winsted and Patterson [53] and Patterson [4], which show that the companies that claim they experience and understand high competitive intensity domestically, maintain greater contact with international markets than those that do not face such domestic pressures.

The variable 'investment in R\&D' also has a positive impact on the decision to internationalize, with a coefficient of 5.66. The companies that have higher investments in $\mathrm{R} \& \mathrm{D}$ maintain regular contacts with international markets, as Patterson [4] argued in his study.

Conversely, the negative and statistically significant degree of unawareness of the foreign market indicates that companies where the risk perception (i.e., unfamiliarity with the market) is higher, have less propensity to internationalize. This relationship had already been determined by several authors ([4], [52-54]) and is now confirmed for the service companies in study.

Finally, it is important to note that some of the elements the literature considered as determinants of the decision to internationalize were not significant for the firms under analysis. This is the case of the expected impact of the perceived cost of operating internationally and the expected return on the decision to operate abroad. We expected that, like Burton and Schlegelmilch [55], Aaby and Slater [52] and 
Leonidou et al. [54], the perception of additional costs in the process of opening to foreign markets would lower the company's willingness to do so and/or the (higher) expected profitability of internationalization would act as an incentive.

\section{Conclusion}

One of the characteristics of economic development is seen in the increasing trend to outsource economies and the ability they have to internationalize services. The remarkable advancements of information and communication technologies have enabled many services to be 'exportable'.

The competitive pressures in domestic markets as well as the globalization of economic activities have encouraged many service companies to seek new business opportunities across borders. Despite the growing importance of trade and intensive investment in services, there are few studies on the internationalization of services, as well as the construction and validation of theories. In fact, the literature on the internationalization of firms tends to focus more on the industrial sector and multinational companies, implying thus the need for additional research in the service sector.

In order to analyze the factors influencing the internationalization of service firms based on a quantitative analysis, we surveyed service companies from the design, architecture and engineering consulting sector. We also conducted an exploratory analysis of different hypotheses based on the literature review. Moreover, a multivariate analysis was employed to ascertain the main determinants of internationalization and the results were compared with studies on other countries, in order to determine similarities and differences among economic, geographic and social distinct realities.

In line with the conclusions of previous studies, firm size is a distinguishing factor between companies that operate internationally and those that do not, both in terms of number of employees and in terms of turnover. Also, the number of employees with international experience is higher in companies operating abroad. We also noted that companies that have managers with more technical and foreign language skills are more open and more prone to internationalize.

The study also allowed us to conclude that companies perceive international markets as riskier, more expensive to operate, but also more profitable than domestic markets. It is also important to note that the main obstacles reported by firms were protectionism of local technicians and businesses, the costs associated with the initial investment and unfamiliarity with external markets, which contradicts some recent studies.

We also noted that competitive pressure is a booster to internationalization.

It is clear that more research on the development of theory and research on the sector are recommended. We believe there is a need to develop new theories that explain and predict the behaviour of a service-oriented company, integrating the various theoretical constructs, including the unique characteristics of services, the country characteristics and the market characteristics. 
Acknowledgement. This work is funded by the ERDF through the Programme COMPETE and by the Portuguese Government through FCT - Foundation for Science and Technology, project PTDC/EGE-GES/099741/2008 and PTDC/EGEGES/117692/2010.

\section{References}

1. OCDE: Annual Report. Paris: The Organisation for Economic Cooperation and Development (2005)

2. Gerbrands, G.: Internationalization of service organizations: a study of the factors that influence the internationalization of service organizations. PhD Thesis, University of Twente, Nederlands (2008)

3. Lejpras, A.: Determinants of internationalization: differences between service and manufacturing SMEs. Deutsches Institut für Wirtschaftsforschung, Paper N. 886 (2009)

4. Patterson, P.G.: A Study of Perceptions Regarding Service Firms' Attitudes Towards Exporting. Australasian Mark. J. 12(2), 19-38 (2004)

5. Javalgi, R.G., Martin, C.L.: Internationalization of services: identifying the building block for future research. J. Services Mark. 21(6), 391-397 (2007)

6. Depreya, B., Lloyd-Reasona, L., Ibehb, K.I.N.: The internationalisation of small-and medium-sized management consultancies: an exploratory study of key facilitating factors. Service Industries J. 32(10), 1-13 (2011)

7. Krull, E., Smith, P., Ge, G.L.: The internationalization of engineering consulting from a strategy tripod perspective. Service Industries J. 32(7), 1097-1119 (2012)

8. Lovelock, C.H., Yip, G.S.: Developing Global Strategies for Service Businesses. California Manage. Rev. 38(2), 64-86 (1996)

9. Bateson, J.E.G., Hoffman, D.K.: Marketing de serviços, 4th edn. Porto Alegre, Bookman (2001)

10. Grönroos, C.: Internationalization strategies for services. J. Service Mark. 13(4/5), 290-297 (1999)

11. Brouthers, K.D., Brouthers, L.E.: Why service and manufacturing entry mode choices differ: the influence of transaction cost factors, risk and trust. J. Manage. Stud. 40, 1179-1204 (2003)

12. Agarwal, S., Ramaswami, S.N.: Choice of foreign market entry mode: impact of ownership, location and internationalization factors. J. Int. Bus. Stud. 23(1), 1-27 (1992)

13. Elango, B., Abel, I.: A comparative analysis of the influence of country characteristics on service investments versus manufacturing investments. Americ. Bus. Rev. 22(2), 29 (2004)

14. O'Farrell, P.N., Wood, P.A., Zheng, J.: Regional influences on foreign market development by business service companies: elements of a strategic context explanation. Regional Stud. 32(1), 31-48 (1998)

15. Javalgi, R.G., Griffith, D.A., White, D.S.: An empirical examination of factors influencing the internationalization of service firms. J. Services Mark. 17(2), 185-201 (2003)

16. Erramilli, M.K.: Entry mode choice in service industries. Int. Mark. Rev. 5(7), 50-62 (1990)

17. Blomstermo, A., Sharma, D.: Choice of foreign market entry mode in service firms. Int. Mark. Rev. 23(2), 211-229 (2006)

18. Erramilli, M.K., Rao, C.P.: Service Firms' International Entry-Mode Choice: A Modified Transaction-Cost Approach. J. Marketing 57(7), 19-38 (1993) 
19. Rosenbaum, S.M., Madsen, T.K.: Modes of foreign entry for professional service firms in multi-partner projects. Service Industries J. 32(10), 1653-1666 (2012)

20. Philippe, J., Léo, P.Y.: Influence of entry modes and relationship modes on business services internationalisation. Service Industries J. 31(4) (2011)

21. Carneiro, J., Dib, L.A.: Avaliação comparativa do escopo descritivo e explanatório dos principais modelos de internacionalização de empresas. INTERNEXT - Revista Electrónica de Negócios Internacionais da ESPM 2(1), 1-25 (2007)

22. Dunning, J.H.: Toward an eclectic theory of international production: Some empirical tests. J. Int. Bus. Stud. 11(1), 9-31 (1980)

23. Dunning, J.H.: The eclectic paradigm of international production: A restatement and some possible extensions. J. Int. Bus. Stud. 19(1), 1-31 (1988)

24. Dunning, J.H.: Reappraising the eclectic paradigm in an age of alliance capitalism. J. Int. Bus. Stud. 26(3), 91-461 (1995)

25. Johanson, J., Vahlne, J.-E.: The internationalization process of the firm - A model of knowledge development and increasing foreign market commitments. J. Int. Bus. Stud. 8, 23-32 (1977)

26. Johanson, J., Vahlne, J.E.: The Uppsala internationalization process model revisited: From liability of foreignness to liability of outsidership. J. Int. Bus. Stud. 40(9), 1411-1431 (2009)

27. Andersen, O.: On the internationalization process of firms: A critical analysis. J. Int. Bus. Stud. 24(3), 209-231 (1993)

28. Cunningham, M.T., Culligan, K.: Competitiveness through networks of relationships in information technology product markets. In: Paliwoda, S.J. (ed.) New Perspectives on International Marketing. Routledge, London (1991)

29. Johanson, J., Mattsson, L.-G.: Network positions and strategic action - an analytical framework. In: Axelsson, B., Easton, G. (eds.) Industrial Networks. A New View of Reality, pp. 206-217. Routledge, London (1992)

30. Bell, J.: The internationalization of small computer software firms: A further challenge to stage' theories. European J. Mark. 8, 60-75 (1995)

31. Bjorkman, I., Forsgren, M.: Nordic international business research: a review of its development. Int. Stud. Manage. Organization 30(1), 6-25 (2000)

32. Andersson, U., Forsgren, M., Holm, U.: The strategic impact of external networks: subsidiary performance and competence development in multinational corporation. Strategic Manage. J. 23(11), 979-996 (2002)

33. Lee, M., Stanley, Y.W.S., Lam, H.: Event and rule services for achieving a Web-based knowledge network. Knowledge-Based Systems 17, 179-188 (2004)

34. Balbinot, Z., Graeml, A.R., Macada, A.A.: A internet e a estratégia de internacionalização das empresas Brasileira. BASE - Revista de Administração e Contabilidade da Unisinos 5(3), 188-197 (2008)

35. Kim, W.C., Hwang, P.: Global strategy and multinationals entry mode choice. J. Int. Bus. Stud. 23(1), 29-53 (1992)

36. Wernerfelt, B.A.: Resource-Based View of the Firm. Strategic Manage. J. 5(2), 171-180 (1994)

37. Barney, J.: Firm resources and sustained competitive advantage. J. Manage. 17(1), 99-120 (1991)

38. Barney, J.: Gaining and sustaining competitive advantage, 2nd edn. Prentice Hall, Upper Saddle River (2002)

39. Ruzzier, M., Hisrich, R.D., Antoncic, B.: SME internationalization research: past, present, and future. J. Small Bus. Enterprise Development 13(4), 476-497 (2006) 
40. Barney, J.B., Hesterly, W.S.: Administração Estratégica e Vantagem Competitiva Casos brasileiros. Pearson Education, São Paulo (2007)

41. Coviello, N.E., McAuley, A.: Internationalisation and the smaller firm: A review of contemporary empirical research. Manage. Int. Rev. 39(3), 223-256 (1999)

42. Wickramasekera, R.G., Oczkowski, E.: Stage models re-visited: a measure of the stage of internationalisation of a firm. Manage. Int. Rev. 46(1), 39-55 (2006)

43. Ghoshal, S.C.A., Barlett, M.P.: A new manifesto for management. Sloan Manage. Rev. 40(3), 41-54 (1999)

44. Castellacci, F.: The internationalization of firms in the service industries: Channels, determinants and sectoral patterns. Technological Forecasting \& Social Change 77(3), 500-513 (2010)

45. Hassel, A., Höpner, M., Kurdelbusch, A., Rehder, B., Zugehör, R.: Two Dimensions of the Internationalization of Firms. J. Manage. Stud. 40(3), 705-723 (2003)

46. Lommelen, T., Matthyssens, P.: The internationalization process of service providers: a literature review. Research on Int. Service Mark.: A State of the Art 15, 95-117 (2005)

47. Coviello, N.E., Martin, K.: Internationalization of service SMEs: an integrated perspective from the engineering consulting sector. J. Int. Mark. 7(4), 42-66 (1999)

48. Zou, S., Fang, E., Zhao, S.: The effects of export marketing capabilities on export performance: An investigation of Chinese exporters. J. Int. Mark. 11(4), 32-55 (2003)

49. Samiee, S.: The internationalization of services: trends, obstacles and issues. J. Services Mark. 13(4/5), 319-336 (1999)

50. Guenzi, P., Pelloni, O.: The Impact of Interpersonal Relationships on Customer Satisfaction and Loyalty to the Service Provider. Int. J. Service Industry Manage. 15(4), 365-384 (2004)

51. Sichtmann, C., Selasinsky, V.M.: Exporting Services Successfully: Antecedents and Performance Implications of Customer Relationships. J. Int. Mark. 18(1), 86-108 (2010)

52. Aaby, N.E., Slater, S.: Management Influences on Export Performance: A Review of the Empirical Literature 1978-1988. Int. Mark. Rev. 6(4), 6-25 (1988)

53. Winsted, K.F., Patterson, P.G.: Internationalization of services: the service exporting decision. J. Services Mark. 12(4), 294-311 (1998)

54. Leonidou, L., Katsikeas, C.S., Piercy, N.F.: Identifying Managerial Influences on Exporting: Past Research and Future Directions. J. Int. Mark. 6(2), 74-102 (1998)

55. Burton, F.N., Schlegelmilch, B.B.: Profile analyses of non-exporters versus exporters grouped by export involvement. Int. Mark. Rev. 1(27), 38-49 (1987)

56. Sacramento, I., Almeida, V.M.C., Silva, M.S.M.: The Internationalization Process of Services Firms: A Two-Case Study in Brazil. Latin American Bus. Rev. 3(2), 43-64 (2002)

57. Yin, R.K.: Case study research-Design and methods, 2nd edn. SAGE Publications (1994)

58. Maroco, J.: Análise Estatística com o PASW Statistics. Editora Report Number (2010) 